\title{
Scenario Planning
}

The link between future and strategy 
This page intentionally left blank 


\section{Scenario Planning}

The link between future and strategy

Revised and updated edition

Mats Lindgren

CEO, Kairos Future

and

Hans Bandhold

Senior Partner, Kairos Future

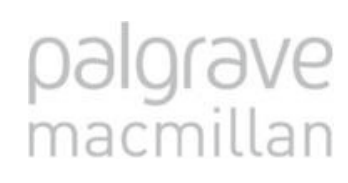




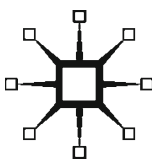

(c) Mats Lindgren and Hans Bandhold 2003, 2009

Softcover reprint of the hardcover 2nd edition 2009 978-0-230-57919-4

All rights reserved. No reproduction, copy or transmission of this publication may be made without written permission.

No portion of this publication may be reproduced, copied or transmitted save with written permission or in accordance with the provisions of the Copyright, Designs and Patents Act 1988, or under the terms of any licence permitting limited copying issued by the Copyright Licensing Agency, Saffron House, 6-10 Kirby Street, London EC1N 8TS.

Any person who does any unauthorized act in relation to this publication may be liable to criminal prosecution and civil claims for damages.

The authors have asserted their rights to be identified as the authors of this work in accordance with the Copyright, Designs and Patents Act 1988.

First edition 2003

Second edition 2009

Published by

\section{PALGRAVE MACMILLAN}

Palgrave Macmillan in the UK is an imprint of Macmillan Publishers Limited, registered in England, company number 785998, of Houndmills, Basingstoke, Hampshire RG21 6XS.

Palgrave Macmillan in the US is a division of St Martin's Press LLC, 175 Fifth Avenue, New York, NY 10010.

Palgrave Macmillan is the global academic imprint of the above companies and has companies and representatives throughout the world.

Palgrave ${ }^{\circledR}$ and Macmillan ${ }^{\circledR}$ are registered trademarks in the United States, the United Kingdom, Europe and other countries

ISBN 978-1-349-36782-5

DOI $10.1057 / 9780230233584$

ISBN 978-0-230-23358-4 (eBook)

This book is printed on paper suitable for recycling and made from fully managed and sustained forest sources. Logging, pulping and manufacturing processes are expected to conform to the environmental regulations of the country of origin.

A catalogue record for this book is available from the British Library.

A catalog record for this book is available from the Library of Congress.

$\begin{array}{llllllllll}10 & 9 & 8 & 7 & 6 & 5 & 4 & 3 & 2 & 1\end{array}$

18171615141312111009 


\section{Contents}

List of figures vii

List of tables $\quad x$

Foreword xi

Introduction $\quad 1$

Chapter 1 Why is Scenario Planning Needed? Some Reasons from the Field of Strategy Research 4

The search for strategic flexibility: a strategic dynamic take-off 5

Dogfights, speed-learning ... 6

... and strategic response capability $\quad 7$

Putting the strategic response theory into perspective $\quad 9$

So how much does strategic flexibility mean? 10

It means more than we think! 11

What makes companies strategically flexible? 16

So: are companies emphasizing the essentials? 19

There is need and there are opportunities! 20

Chapter 2 Scenario Planning: An Introductory Overview 22

What are scenarios and scenario planning? 22

Developing scenarios 33

A brief history of scenario planning $\quad 34$

TAIDA $^{\text {TM}}$ : a framework for thinking of the future $\quad 39$

Scenario planning and leadership 43

Paradoxes in scenario planning 44

When can scenario techniques be used? $\quad 46$

Chapter 3 Scenario Planning in Practice 49

TAIDA $^{\text {TM}}$ : the method for scenario planning 49

Preparations $\quad 50$

Task and prerequisites $\quad 55$

$\begin{array}{ll}\text { Tracking } & 59\end{array}$

Analysing $\quad 65$

Imaging $\quad 82$

$\begin{array}{ll}\text { Deciding } & 88\end{array}$ 
Acting

How to organize continuous futuristic work 103

$\begin{array}{ll}\text { Scenario planning for crises } & 108\end{array}$

Twenty-four pitfalls

Chapter 4 The Principles of Scenario Thinking

The seven principles of scenario thinking

Principle 1: Get yourself a toolbox

Principle 2: Handle your brain with care $\quad 124$

Principle 3:Think in dramas $\quad 126$

Principle 4:Think in futures $\quad 127$

Principle 5:Think in uncertainty $\quad 129$

Principle 6:Think in systems $\quad 130$

Principle 7:Think in actors and moves $\quad 135$

$\begin{array}{lll}\text { Chapter } 5 & \text { The Principles of Strategic Thinking } & 138\end{array}$

Principle 1:Think in paradoxes 138

Principle 2: Think in visions $\quad 140$

Principle 3:Think in jamming $\quad 141$

Principle 4:Think in time $\quad 142$

Principle 5:Think in resources 143

Principle 6:Think in life cycles $\quad 144$

Principle 7:Think in experiments and bets $\quad 145$

Appendix 1: Methods 147

Media-based methods $\quad 147$

Interview-based methods $\quad 149$

Timeline-based methods $\quad 154$

Intuitive, generative methods $\quad 160$

Actor-oriented methods $\quad 164$

Consequence-focused methods $\quad 166$

Systems methods $\quad 170$

$\begin{array}{ll}\text { Appendix 2: Glossary } & 182\end{array}$

$\begin{array}{lr}\text { Notes } & 189\end{array}$

Kairos Future $\quad 191$

Bibliography 192

Further reading 196

Index 197 


\section{Figures}

1.1 Illustration of the OODA Loop

1.2 Illustration of the strategic response capability

7

1.3 The key challenge to business leaders is to manage the balance between robustness and responsiveness and to avoid vicious circles

1.4 Four levels of proactiveness: from cleaner to shaper

1.5 There are several similarities between successful companies and a jam session

1.6 The abilities to 'think, play and garden' are the three organizational behaviours that most strongly predict performance in turbulent business environments

1.7 Different types of organizational anomalies

1.8 The diagram illustrates that that most companies have a huge performance potential through a stronger emphasis in thinkingrelated practices

2.1 Feedback: historical results, evaluation

2.2 The relations between possible, probable and desired futures

2.3 Scenario projects could be used for different purposes and with different focuses

2.4 Scenario planning is the combination of scenario analysis for strategic purposes and strategic planning based on the outcome of the scenario phase

2.5 Scenario planning is well suited to the task of dealing with paradigmatic, non-linear change

2.6 Development of paradigm-challenging strategies requires the integration of high-level strategic thinking and a strong emphasis on futures thinking

2.7 Three levels of integration in today's corporations 31

2.8 The two 'brain-halves' of the organization 44

2.9 Different planning situations where scenarios are useful 47

3.1 Overview of the TAIDA process 50

3.2 The outside-in perspective of scenario planning 60

3.3 Trends are based on observed changes in the present 61

3.4 A model for a first prioritization of trends 62

3.5 Example of trends identified in a project concerning The Future of Crime 
3.6 An example of a causal-loop diagram for The Future of Crime illustrating the strongest relationships between the identified trends

3.7 The relation between scenarios and certain trends compared with a play in the theatre

3.8 The timeline from the projected Future of Crime

3.9 Scenario cross that constitutes four different scenarios based on two uncertainties

3.10 Overview of the scenarios of The Future of Crime

3.11 Example of a narrative scenario description from The Future of Crime

3.12 Extract from the scenario comparison concerning The Future of Crime

3.13 Four global scenarios on the future of newspapers 80

3.14 The components of a vision 83

3.15 The tension between vision and reality 87

3.16 A consequence tree 90

3.17 The clustering process $\quad 92$

3.18 The WUS model 94

3.19 Example of WUS analysis in a service-sector company 95

3.20 Example of causal-loop diagram used for strategy analyses 97

3.21 Strategies versus life cycle: an example from the service industry 98

3.22 An overview of the TAIDA process 100

3.23 Overview of a number of examples of occurrences in the environment that have an impact on the probability of the realization of the different scenarios

3.24 The seven key success factors in turbulent business environments

3.25 Example of a typical TRIM process 108

4.1 Model of the organizational business context and its parallel to Boulding's systems model

4.2 The iceberg metaphor: structural changes are driving systems at lower levels and are eventually observed as events and actions

A.1 Example of a Gapminder graph of world population and development

A.2 The paradigm shift and the problems on the shelf 160

A.3 Example of an intuitive timeline 161

A.4 Model for an actor analysis using the mind-mapping technique

A.5 Single-impact analysis 168

$\begin{array}{lll}\text { A.6 Probability effects } & 169\end{array}$ 
A.7 Example of a scheme that can be helpful for a collected assessment of trends, effects, probability and knowledge

A.8 Example of complexity and uncertainty analysis

A.9 Raplexity-diagram to plot the business ecosystem's raplexity (complexity and speed of change)

A.10 Different types of uncertainties on different complexity levels and their matching strategies

A.11 Example of cross-impact analysis with six trends or variables 174

$\begin{array}{lll}\text { A.12 Cross-impact diagram } & 175\end{array}$

A.13 Example of positive feedback loop, self-reinforcing system 176

A.14 Example of a system with a negative feedback look, a self-regulating system

A.15 Illustration of a common situation for small companies 178

$\begin{array}{ll}\text { A.16 Advantages of system models } & 180\end{array}$

$\begin{array}{ll}\text { A.17 Example of a model created in Ithink } & 181\end{array}$

A.18 EPISTLE: a system to scan the environment 184

A.19 The prospective view of the future as a multiplicity of alternatives 


\section{Tables}

1.1 Overview of some concepts of 'strategic flexibility'

2.1 Differences between scenarios, forecasts and visions 25

2.2 Characteristics of traditional planning compared with the scenario-planning approach

2.3 Three models for carrying out a scenario project

4.1 Boulding's seven levels of open living systems

5.1 Strategic choice behaviour 


\section{Foreword}

The first years of the new millennium have clearly pointed to the need to prepare for the non-preparable. The dangers of failing to prepare were shown in the aftermath of an insane race on the world's stock markets around the year 2000 when ICT and telecom shares hit new highs every week, but a year later many hit historical lows.

Could the 2001-02 downturn have been foreseen and prepared for, and thus even been possible to capitalize on? Could the rising oil prices, the race for natural resources and the global warming shock in 2007-08 have been foreseen? Or even the financial crises in September 2008? We believe so. Much of what happened, both during the dot.com boom and during recent years, was not at all unthinkable; it could have been imagined. The potential problems with the 3G launch were already clearly foreseeable in the year 2000, when European governments made big money out of the $3 \mathrm{G}$ race. That could have been a wake-up call for everybody involved. ${ }^{1}$ The insane prices on dot.coms during 1999 and 2000 were another sign, and were interpreted correctly by some brave investors. The food and energy shock was a quite natural result of the combination of booming economies in the East and agricultural politics in the West, and oil became even more significant for geopolitics several years before the price took off. The 2008 financial crisis and the government interventions that followed were predicted accurately by one of our colleagues in spring 2006 in a report for our knowledge communities. Even the global stock-market race in the 1980s, as well as the crises that followed, could have been anticipated using simple economic long-wave theory.

Scenario planning is a powerful tool for anticipating and managing change on an industry level or environmental level, and scenario thinking is the strategic perspective necessary in today's turbulent business environment. Scenario thinking incorporated into scenario planning is useful in almost any strategic question in today's businesses. Scenario planning is clearly the link between futures thinking and strategic action, between creative, innovative and imaginative futurizing and the more hands-on strategic 
planning. And strategic planning, or strategizing, without scenario thinking is more or less pointless.

In this book, our aim is to introduce the concept of scenario thinking and scenario planning and to provide our readers with some concepts, models and tools to take back to their own companies. It is based on almost two decades of experience of scenario planning as a strategic tool, where we as consultants have guided multinationals and medium-sized companies as well as governments and non-governmental organizations in these approaches.

We would also like to take the opportunity to thank our clients and our colleagues at Kairos Future for countless inspiring dialogues. We also want to thank our families for their understanding and support during the process of writing the book.

We hope that you as a reader will find it useful. Please feel free to contact us for comments.

Mats Lindgren and Hans Bandhold 